\title{
Ice charting based on multispectral satellite data in the Baltic Sea
}

\author{
V. A. Golovko, \\ NPO Planeta, Bolshevistskaya St. 7, 123376 Moscow, Russia \\ M. LEPPÄRANTA, \\ Department of Geophysics, P.O. Box 4 (Fabianinkatu 24A), SF-00014 University of Helsinki, Finland \\ S. KALLIOSAARI, \\ Finnish Institute of Marine Research, P.O. Box 33, SF-00931 Helsinki, Finland \\ Yu. S. SEdunOv and A. M. Volkov \\ NPO Planeta, Bolshevistskaya St. 7, 123376 Moscow, Russia
}

\begin{abstract}
Results are presented from an experiment concerning operational space-borne ice charting based on the Russian Ocean and Resource satellite systems. The surface truth consisted of routine operational data, helicopter-borne reconnaissance, and some ground measurements. Examples of the satellite imagery are given and identification of ice types is described. Cluster-analysis has been used for automatic image segmentation. The potential of these satellites in operational ice charting is discussed. A $160 \mathrm{~m}$ resolution optical scanner and a $2 \mathrm{~km}$ resolution radar are found to be very useful complements to the present routine system.
\end{abstract}

\section{INTRODUGTION}

Ice occurs annually in the Baltic Sea for up to six months. Due to the needs of winter shipping, operative ice charting is performed daily by the Ice Service of the Finnish Institute of Marine Research (FIMR). The principal sources of ice information are remote sensing satellites, primarily the NOAA series. These provide an excellent basis but have some limitations. Their reliability is weather-dependent and the spatial resolution $(1.1 \mathrm{~km})$ is limiting for local ice observations.

Research is in progress to develop remote-sensing methods further, e.g. utilisation of the ERS-1 satellite (Leppäranta and others, 1993). This new research also includes examination of the potential for using the Russian Ocean and Resource series satellites (Golovko and others, 1991).

Ocean and Resource satellites provide new additional input to local ice mapping systems through two windows: high to moderate resolution $(30-300 \mathrm{~m})$ optical scanners and a low resolution $(2 \mathrm{~km})$ radar. The goal of the project is to examine the use and usefulness of a real-time data transmission system whereby (1) the satellite data are received in Moscow by NPO Planeta, (2) the data are pre-processed at NPO Planeta, (3) products are transmitted to Helsinki via telephone, and (4) the products are integrated into the Ice Service ice charting system.
This paper considers an experiment in March 1990 in the Bay of Bothnia, northern Baltic Sea, consisting of validation and real-time data transmission of sensed ice conditions.

\section{THE EXPERIMENT}

Routine ice charts and reports provide information for the validation of the satellite-sensed data. These are produced daily by the FIMR Ice Service and are based on NOAA/ AVHRR data, aerial reconnaissance, observations at coastal stations and observations from icebreakers. The data describe ice type, ice concentration, ice and snow thickness, ridging intensity, and the occurrence of leads. For this experiment in March 1990, additional ice information was obtained from a specific measurement campaign (Leppäranta and others, unpublished).

\section{Ice and weather conditions}

The ice season 1989/90 was very mild, of a kind that occurs on average less than once a decade. In March the Bay of Bothnia was 50 to $70 \%$ ice-covered (Fig. 1). The best satellite data were produced on 3 and 24 March. On these days the ice extent was similar, but other ice conditions and meteorological conditions were markedly different. 


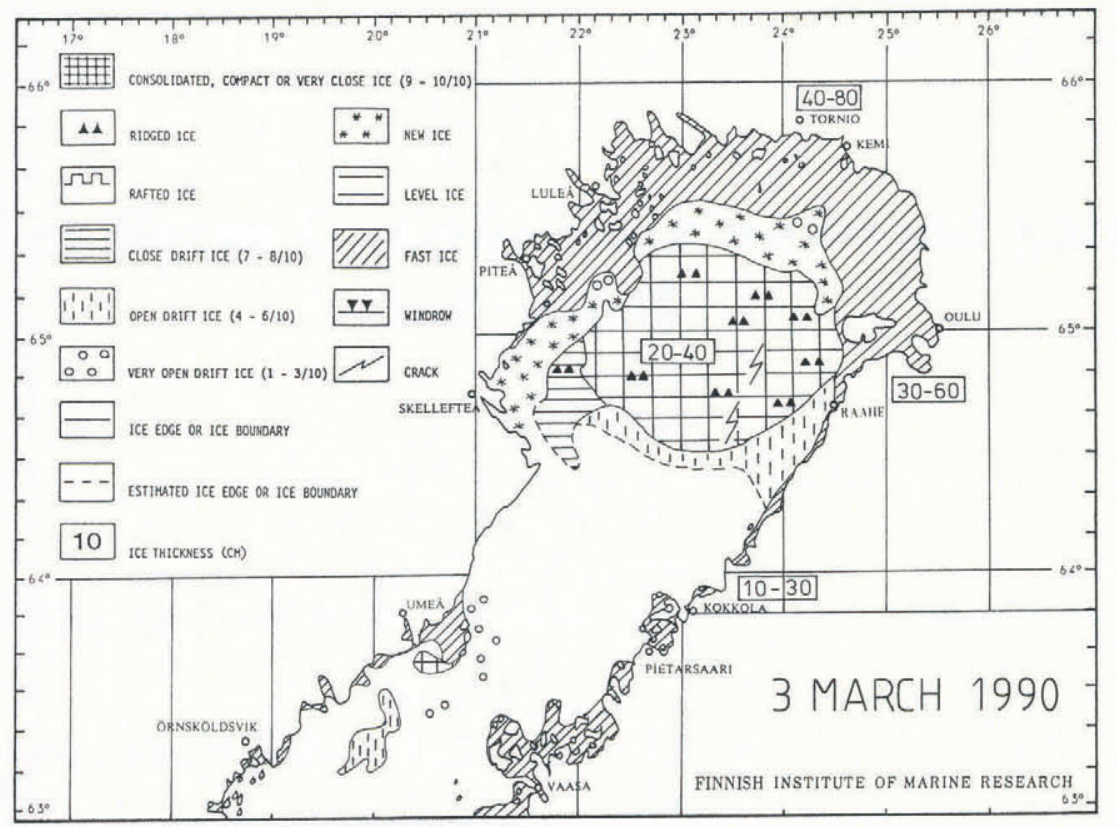

a

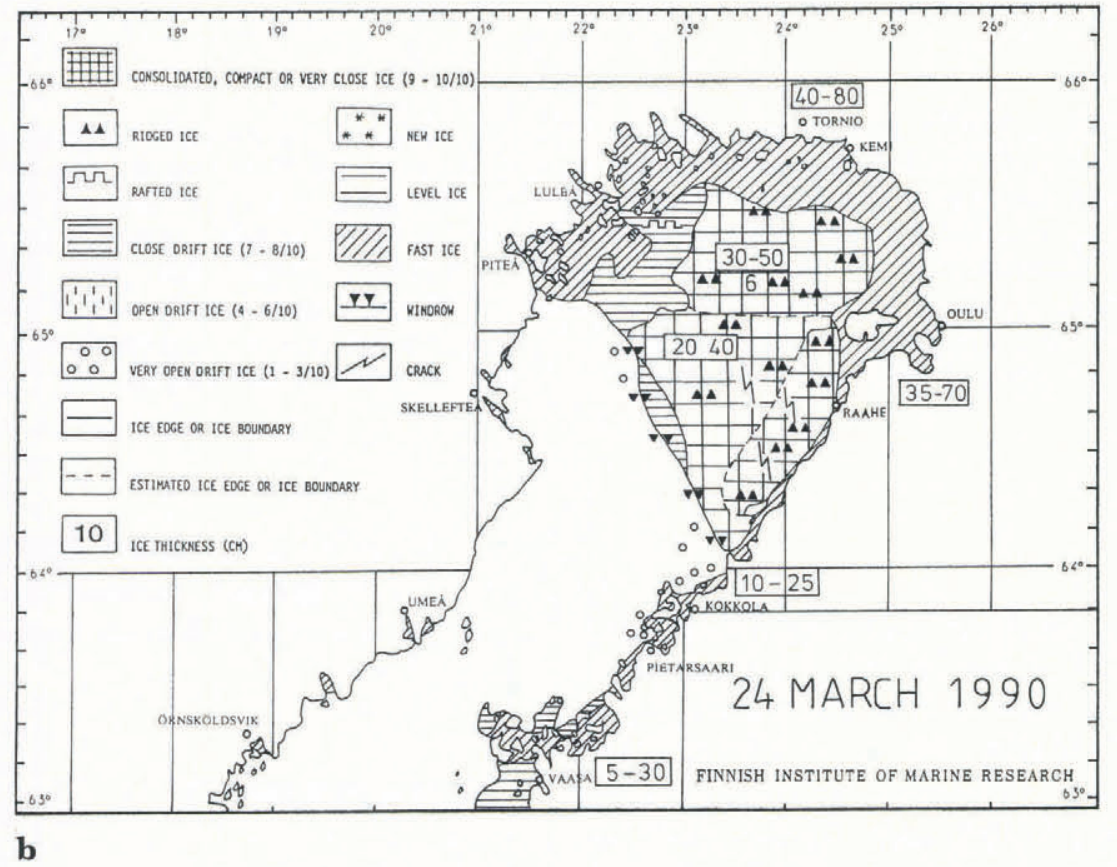

Fig. 1. Ice conditions in the Bay of Bothnia on a, 3 March 1990, and b, 24 March 1990.

Meteorological conditions on 3 March were near average for the mid-winter period. Air temperature was -4.2 to $-6.6^{\circ} \mathrm{C}$ and the wind was 8 to $12 \mathrm{~m} \mathrm{~s}^{-1}$ from the northwest. There was fast ice on the coast and archipelago areas in the Bay of Bothnia (Fig. 1a), 40 to $80 \mathrm{~cm}$ thick in the north decreasing to 10 to $30 \mathrm{~cm}$ in the south. Snow thickness was 5 to $15 \mathrm{~cm}$. In the north and west there was a 10 to $20 \mathrm{~km}$ wide lead at the fast-ice edge. The heaviest pack ice was concentrated in a patch about $100 \mathrm{~km}$ wide, consisting of ice floes 20 to $40 \mathrm{~cm}$ thick and up to $2 \mathrm{~km}$ wide; between the floes there was new ice. Ridges were most frequent in the northern side, with sail heights typically 0.3 to $0.5 \mathrm{~m}$. In the south the surface was in places bare. Further south, beyond the heavy pack ice, there was a narrow zone of open drift ice, concentration 4 to $6 / 10$; the thickness of ice was 10 to $30 \mathrm{~cm}$ and the surface was mostly bare. The ice edge was located at $64^{\circ} 30^{\prime} \mathrm{N}$.

Cold weather prevailed until mid-March. The spring melting season began with strong winds from the southwest compressing the ice northeast and causing the ice edge to shift slowly. New ridges formed in the drift ice field. On 24 March the air temperature was -1.8 to $+0.3^{\circ} \mathrm{C}$. The ice edge lay in the centre area of the basin (Fig. 1b). Off the fast ice boundary there was a heavily ridged ice field, thickness 30 to $50 \mathrm{~cm}$. There were also leads and cracks in the boundary region. Southwest from the heavily ridged ice field there was 20 to $40 \mathrm{~cm}$ thick very close drift ice consisting of floes 1 to $100 \mathrm{~m}$ wide, partly frozen together. At the ice edge there was a 200 to $400 \mathrm{~m}$ wide brash ice belt. The ice surface was bare in places. Snow, when it occurred, was very wet and melt ponds existed in both drift-ice and fast-ice regions. 


\section{Satellite data}

NPO Planeta Scientific-Industrial Corporation exploits the Russian space systems Meteor-2 and-3, Ocean-01 and Resource-01 (Vasuyukhina and Volkov, 1988). Ocean-01 and Resource-01 are studied for Ice Service ice mapping systems. Ocean-01 has an X-band Side-Looking Radar (SLR) with about $2 \mathrm{~km}$ resolution and $450 \mathrm{~km}$ swath width. Simultaneous pictures from the SLR and from an optical scanner with the same scale and space resolution are provided for Arctic shipping in the Northern Sea Route. Resource-01 is equipped with optical and infrared sensors for more accurate mapping of the earth's surface. For ice mapping in the Baltic Sea the Multizonal Conical Scanner with Moderate Resolution (MS-MC) is expected to be very helpful. For a swath width of $600 \mathrm{~km}$, the system has four channels in the optical and near-infrared regime with $160 \mathrm{~m}$ resolution and one thermal infrared channel with $600 \mathrm{~m}$ resolution. Table 1 shows the data collected for further analysis in the March 1990 experiment. They consist of two Resource-01 MS-MC images and two Ocean-01 SLR images.

Table 1. The satellite data for the experiment in March 1990

Satellite

Channels

Time

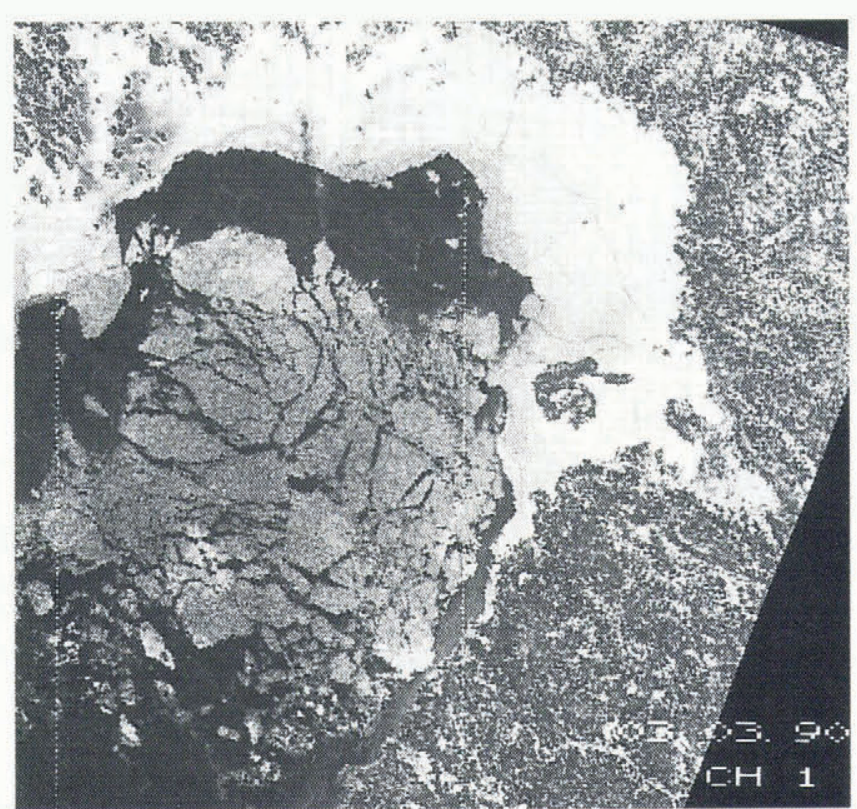

a

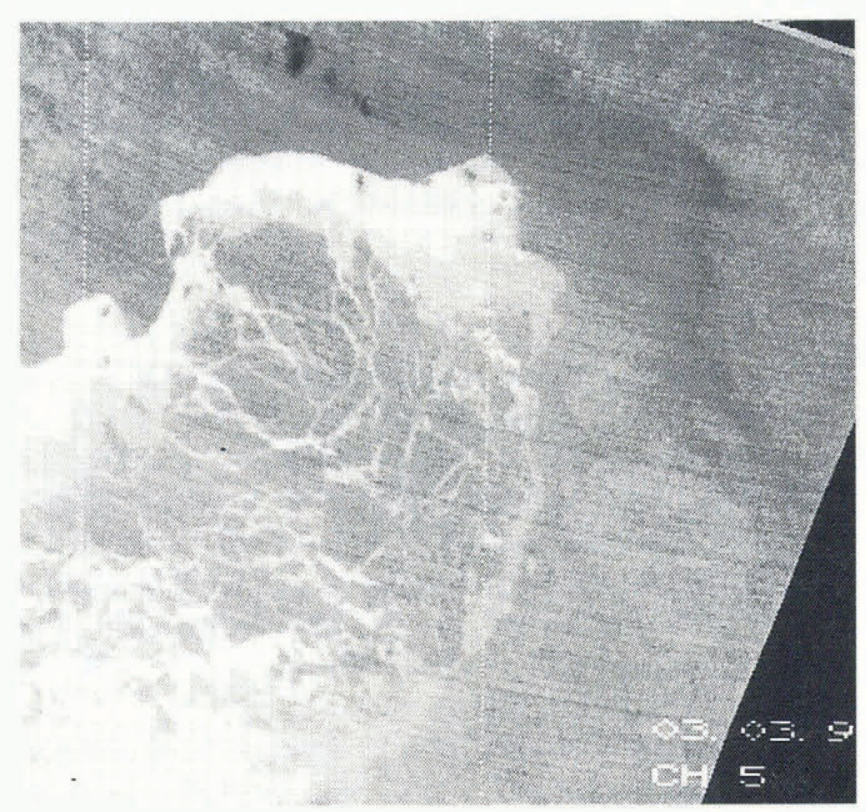

b

Fig. 2. Image over the Bay of Bothnia taken with Resource-01 MS-MC, 3 March 1990. a, channel 1 (0.5$0.6 \mu \mathrm{m})$ and $b$, channel $5(8.0-11.6 \mu \mathrm{m})$.

fractures. The thermal image shows the surface temperature differences. The more ice and snow, the colder the surface. The leads are best seen in the thermal image which shows high contrast between open water and older ice. At the lead edges there appear colder zones which are due to new ice production. These new ice zones do not show up well in the other channels. For the 24 March case the interpretation of the imagery is more difficult since much of the contrast has disappeared due to the melting of snow during the month. The near-infrared channel data are shown, for example, in Figure 3. The ice edge in this image is remarkably clear.

To produce objective satellite information on ice fields, cluster analysis was performed on the data. The algorithm used is a so-called self-teaching system which uses a $16 \times 16$ or $32 \times 32$ base grid and a Euclidean 


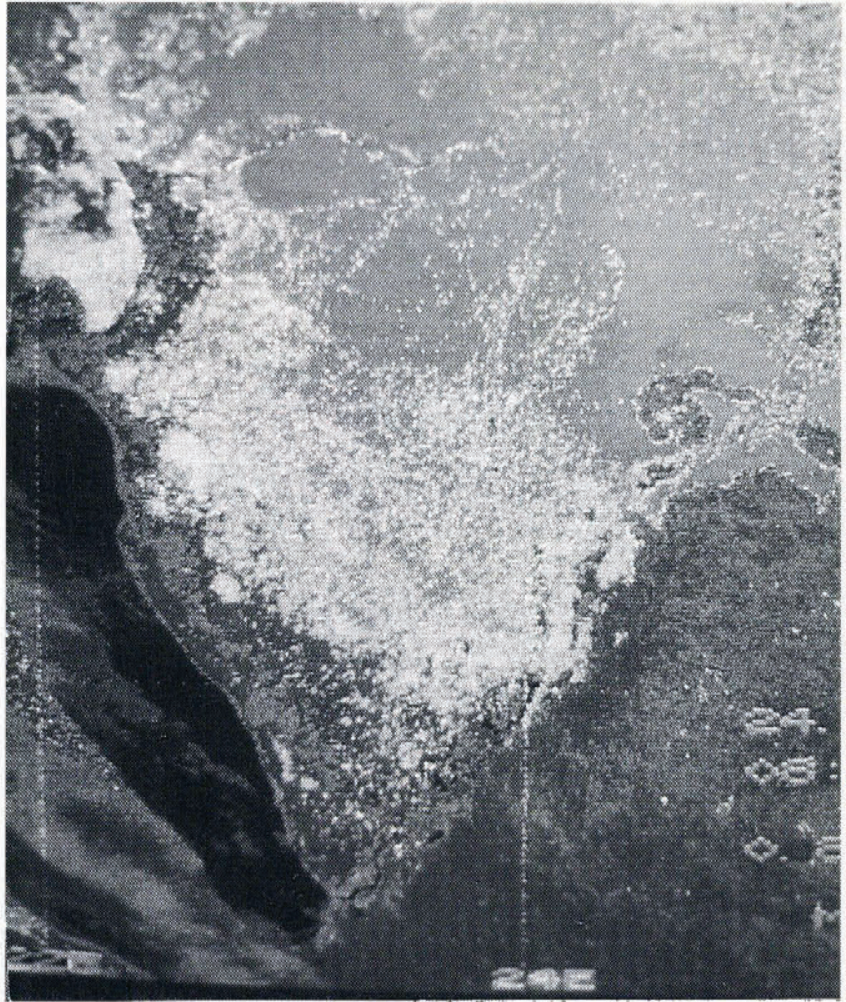

Fig. 3. Image over the Bay of Bothnia taken with Resource-01 MS-MC, 24March 1990. Channel 4 (0.8$1.1 \mu \mathrm{m})$.

distance measure for the multi-channel pixel values. This algorithm, tested earlier on NOAA/AVHRR data, has been found useful for ice-field classification (Golovko and Pakhomov, 1988; Golovko, 1990). For the $16 \times 16$ grid the mean brightness varied within 1 to $20 \%$, while the standard deviation did not exceed $5 \%$. A set of 10 clusters was found characteristic for the present imagery. The most informative channels for 3 March were sets $\{4,1,5\}$ and $\{4,1\}$ and for 24 March, set $\{2,4\}$.

Comparisons between cluster analysis products and one-channel images show that this method is able to reveal new features in the ice field (Fig. 4). For the 3 March case, the snow-covered consolidated ice is much more clearly discriminated in the cluster analysis product. This is also true of new ice and open water. The ridged ice zone at the fast-ice edge becomes observable in the cluster analysis product. For the 24 March case supporting results were obtained. New ice was well discriminated from open water and from older and thicker consolidated floes.

\section{Ocean-01 radar}

In March 1990 two radar images were obtained (Table 1). The quality was not high because the relatively wet surface conditions smoothed much of the contrast in the backscatter intensity. Figure 5 shows the radar image for 28 March. It can be compared with the ice chart for 24 March shown in Figure 1b. It is easy to recognise the coast, the coastal fast-ice zone (low backscatter), drift ice (variable return strength), and then the open water (low backscatter). Although no details can be seen, it is clear that this kind of all-weather ice information might be particularly valuable in bad weather conditions. Lost

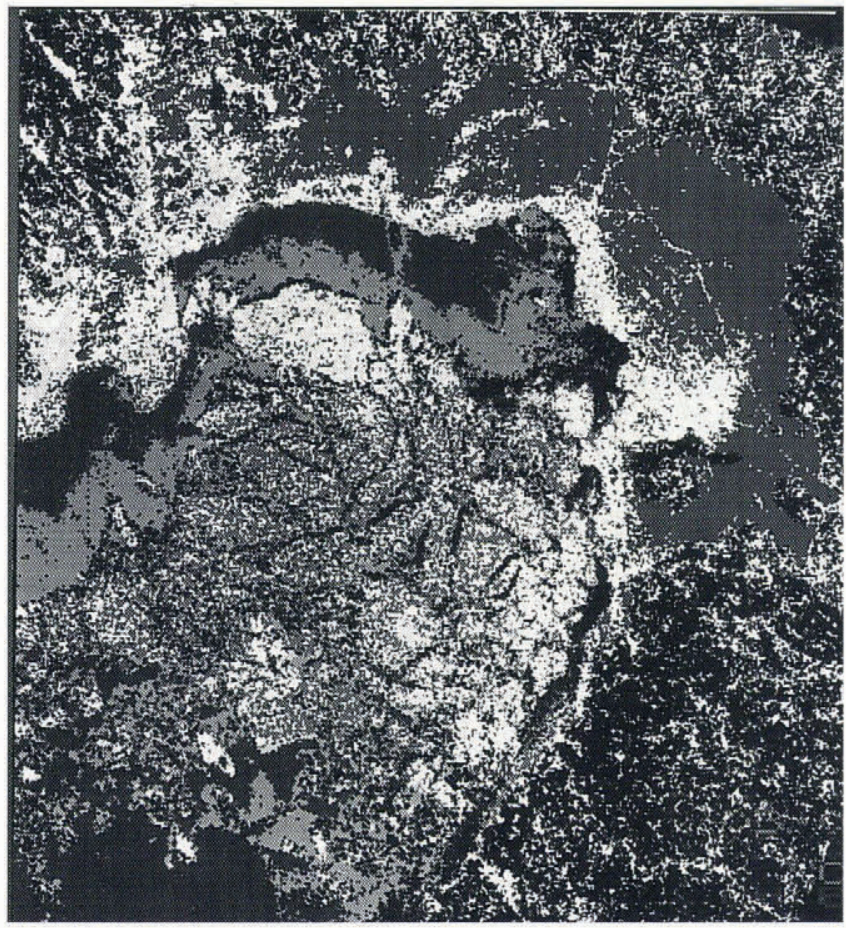

a

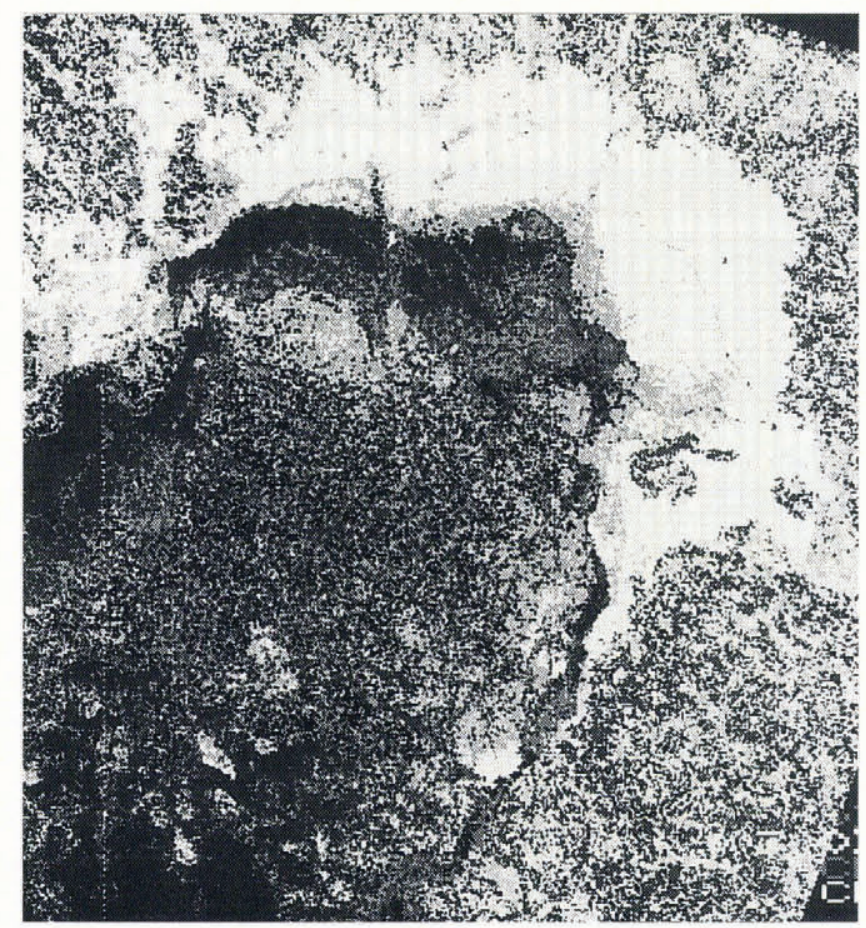

b

Fig. 4. Cluster analysis results for 3 March 1990. a, 10 clusters, channels 1, 4 and b, 14 clusters, channels 1, 4, 5 .

structure detail in low-resolution radar images was also pointed out by Askne and others (1992) for the Baltic Sea.

\section{DISGUSSION AND CONGLUSIONS}

Preliminary results have been presented here, from a joint Russian-Finnish project aimed at utilising Ocean and Resource-series satellites in operational ice charting in the Baltic Sea. The work is based on a campaign in March 1990 in the Bay of Bothnia. The original satellite data 


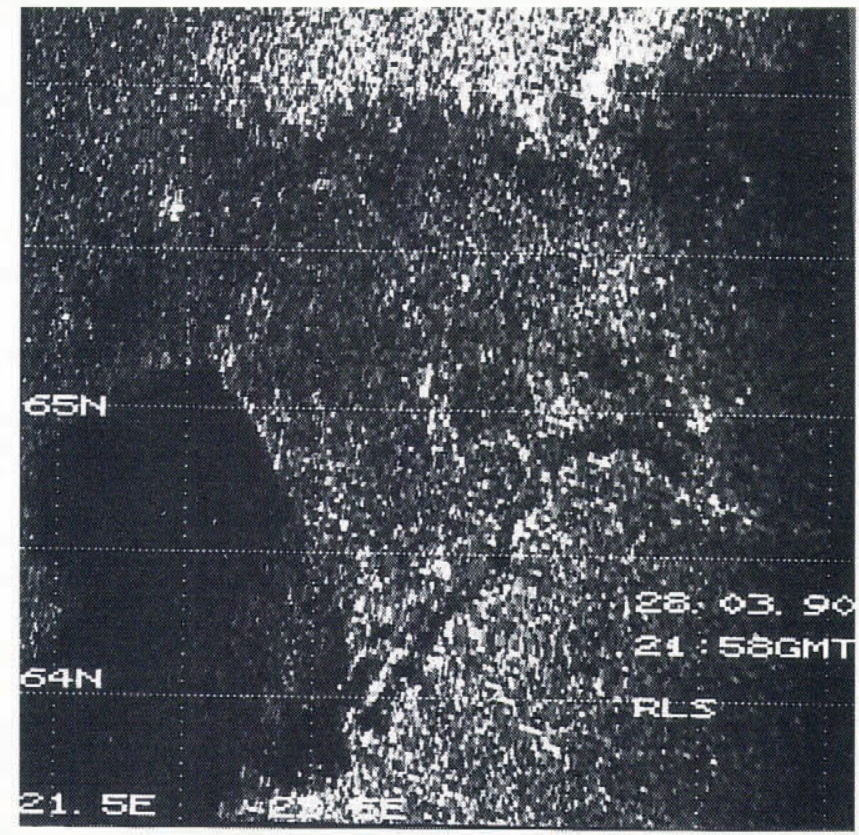

Fig. 5. Ocean-01 Side-Looking Radar image over the Bay of Bothnia, 28 March 1990.

showed very good correspondence with independently produced ice charts. The use of cluster analysis for analysing the multichannel satellite images revealed features which were not well seen in the original onechannel data. Clusters coincided with ice types and open water and described in more detail the structure of the ice pack.

The results lead to the following conclusions: (1) moderate resolution (160 to $320 \mathrm{~m}$ ) optical and nearinfrared imagery is very useful for Baltic Sea ice mapping, (2) the use of low resolution $(2 \mathrm{~km})$ side-looking radar seems promising although problems of interpretation need further research and (3) cluster analysis is a powerful aid for ice-type classification. Research into techniques for further utilising the Ocean and Resource satellite data is presently in progress. In particular, a realtime ice monitoring campaign was incorporated in the International Space Year (1992) activities in the Baltic Sea (Strübing and others, 1991). However, the 1992 ice season was particularly mild and a new campaign is still required to evaluate the Ocean and Resource systems fully.

\section{AGKNOWLEDGEMENTS}

We thank E. S. Golubeva, E. A. Vasiliev, T. V. Bondina, T. V. Hizhnaja and O.C. Bugrova in Moscow for providing satellite information. We also thank Dr Einar-Arne Herland and Mr Yrjö Rauste, the Technical Research Centre of Finland (VTT) for their help concerning data transmission questions.

\section{REFERENCES}

Askne, J., M. Leppäranta and T. Thompson. 1992. The Bothnian Experiment in preparation for ERS-1, 1988 (BEPERS-88) - an overview. Int. f. Remole Sensing, 13 (3), 2377-2398.

Golovko, V.A. 1990. Issledovanie osobennosti identifikatsii bezoblachnykh na osnove nabora dannykh Mezhduharodnogo proekta po klimatologii oblachnosti sputnikovoj [Investigating features of identification of cloudlessness on the basis of selected data from the International Project on Satellite Climatology of Cloud Cover]. Trudy Gos.NITSIPR, 38, 130-134.

Golovko, V.A. and L. A. Pakhomov. 1988. Identifikatsiya oblachnosti na osnove sputnikovykh mnogospektral'nykh dannykh vysokogo prostranstvennogo razresheniya [Identifying cloud cover using multispectral data of high spatial resolution]. Trudy Gos.NITSIPR, 30, 95 111.

Golovko, V.A. and 6 others. c. 1991. Computer-based technology experiment on digital image transmission via telephone lines. In Putkonen, J., ed. IGARSS'91. Remote sensing: global moniloring for Earth management. 1991 International Geoscience and Remote Sensing Symposium, Helsinki University of Technology, Espoo, Finland, June 3-6, 1991. Proceedings. Vol. 2. Abstract. Institute of Electrical and Electronics Engineers, 829

Leppäranta, M., M. Similä, S. Kalliosaari, P. Kosloff, E. Palosuo and J. Rapo. Unpublished. SAAMEX (Surface and Atmospheric Airborne Microwave Experiment) sea ice data report. Helsinki, Finnish Institute of Marine Research. (Internal Report 1990(9).)

Leppäranta, M. and 7 others. 1993. Finnish ERS-1 Baltic Sea ice experiment in winter 1992. In Proceedings of the First ERS-1 Workshop. Vol. 1. Noordwijk, European Space Agency, 307-312. (ESA SP-359)

Strübing, K., M. Leppäranta, R. Ramseier, S. Sandven, O. Johannessen and E.-A. Herland. 1991. A feasibility study of an IS r real time ice monitoring demonstration. Final report. Noordwijk, European Space Agency. (ESA/ESTEC Contract 9115/90/NL/PP(SC).

Vasuyukhina, T. M. and A. M. Volkov. 1988. State-of-the art and prospects for Earth resources and hydrometeorological satellite system development. Moscow, State Research Centre of Earth Resources Exploration. USSR State Committee for Hydrometeorology.

The accuracy of references in the text and in this list is the responsibility of the authors, to whom queries should be addressed. 